\title{
Effect of Cultivation on Organic Carbon Pools and Nutrient Availability in Soil under Different Land Use System: A Review
}

\author{
Usha Kaushik $^{1 *}$, Dev Raj ${ }^{2}$, Pooja Rani ${ }^{2}$ and K.K. Bhardwaj ${ }^{2}$ \\ ${ }^{1} U A S, G K V K$, Bengaluru, Karnataka, India \\ ${ }^{2}$ Department of Soil Science, CCS Haryana Agricultural University Hisar, Haryana, India \\ *Corresponding author
}

\begin{tabular}{|l|}
\hline K e y w or d s \\
$\begin{array}{l}\text { Organic carbon, Light } \\
\text { fraction carbon, Nutrients } \\
\text { availability, Microbial } \\
\text { biomass carbon }\end{array}$ \\
\hline Article Info \\
\hline $\begin{array}{l}\text { Accepted: } \\
\text { 10 July 2018 } \\
\text { Available Online: } \\
\text { 10 August } 2018\end{array}$ \\
\hline
\end{tabular}

\section{Introduction}

Soil organic matter, of which carbon is a major part, holds a great proportion of nutrients, cations and trace elements that are of importance to plant growth. The distribution of soil organic carbon (SOC) within different pools is an important
Soil organic carbon (SOC) is an essential component of soil organic matter and being dynamic in nature controls the nutrients release as well as their availability. Different fractions of organic carbon plays different role in governing the nutrient availability. The various fractions of SOC includes- microbial biomass carbon (MBC), dissolved organic carbon (DOC), light and heavy fraction carbon pool. Among these fraction MBC and DOC fractions are readily soluble or highly mineralizable while heavy fraction carbon constitute the resistant fraction and account higher percentage compared to all other fractions. DOC accounts smallest fraction but it is directly involves in plant nutrition. Microbial biomass carbon was reported higher $\left(430.7 \mu \mathrm{g} \mathrm{g}^{-1}\right)$ under forest land use system followed by organic farming $\left(230.0 \mu \mathrm{g} \mathrm{g}^{-1}\right)$ land use system while both these system are significantly higher in $\mathrm{MBC}$ as compared to agricultural and riverine land.). Agricultural soil has 5075\% less C stocks compare to reference site which is under native forest. Light fraction carbon (LFC) comprised largely of incompletely decomposed organic residues, may provide a sensitive indicator of the effects of cropping practices on soil organic matter. Soil under no tillage and forest preserved respectively $167 \%$ and $94 \%$ more LFC than those under conventional tillage. Conversion of native forests and pristine soils to cultivation is usually accompanied by decline in SOC and deterioration of soil structure. Trees had long been found to increase organic carbon, extractable $\mathrm{P}$, and exchangeable cations. The soil solution concentration of $\mathrm{N}, \mathrm{P}, \mathrm{S}$ and several micronutrients are intimately related to organic fraction in soil. Altering land use system have multiple effects on soil properties and nutrients availability. 
(Guo and Gifford, 2002). Soil organic carbon fractions, such as microbial biomass carbon and light fraction organic carbon generally respond more rapidly to changes in land use systems than total organic carbon content. Soil microbial biomass constitutes a transformation matrix for natural organic materials in soil and acts as a labile reservoir of plant available nutrients (Maia et al., 2007 and Lakaria et al., 2012).

Small change in soil organic carbon pools could have significant impact on atmospheric $\mathrm{CO}_{2}$ concentration in future (Smith et al., 2008). The changes in soil quality caused by different types of land use must be quantified prior to selecting the most sustainable type of use and management that will minimise the soil disturbances. The effect of cropping systems and management practices on soil properties provide essential information for assessing environment impact.

There is considerable concern that land use change could alter soil carbon (Houghton, 1999) and nitrogen (Potter et al., 1996) cycle. Nitrogen is the most required plant nutrient, which is found in several chemical forms in soil (Cantarella, 2007), resulting in a very dynamic behaviour. Land-use changes affect the soil carbon storage and cause quantitative and qualitative changes on soil organic matter and consequently on physical and chemical characteristics that directly affect the nutrient availability to the plants (Bayer and Mielniczuk, 2008).

The changes in soil quality caused by different types of land use must be quantified prior to selecting the most sustainable type of land use and management that will minimise the soil disturbances. Keeping in mind the above facts the present document is prepared highlighting the influence of different land use system on organic carbon pools and nutrient availability in soils of different agro ecological regions.

\section{Soil organic carbon}

Soil organic carbon is the second largest carbon pool on the surface of the earth after the oceans (Swift, 2001) and the possibility of increasing the organic carbon content of the soil through changing agronomic management practices may play a role in combating climate change (Lal, 2002). Although the amount of SOC in soils of India is relatively low, ranging from 0.1 to $1 \%$ and typically less than $0.5 \%$, yet its influence on soil fertility and physical condition is of great significance (Swarup et al., 2000). Organic matter (OM) acts as the storehouse of essential nutrients and source or sink to atmospheric $\mathrm{CO}_{2}$ and act as major factor in overall health (Lal, 2002; Mishra et $a l ., .2002)$.

The clearing of forest and subsequently cultivation and tillage practices resulted in the decline of the soil quality and these changes affects on soil sensitivity to degradation and erosion (Sharif Abad et al., 2014). Conversion of forest or silvipastoral system to arable lands is expected an effective decrease in soil carbon stocks (Haile et al., 2008; Apezteguia et al., 2009). Martinez-Mena et al., (2008) had done an experiment to evaluate the impact of cultivation on the soil carbon dynamic and carbon stock in a semiarid area of south-east Spain. They concluded that change inland use from forest to cultivate reduced the soil carbon stock (in the top $5 \mathrm{~cm}$ ) by about $50 \%$. The conversion of forest ecosystem to other forms of land cover may decrease the stock of SOC due to changes in soil moisture and temperature regimes, and succession of plant species with differences in quantity and quality of biomass returned to the soil (Offiong and Iwara, 2012). The SOC is recognized to consist of various fractions varying in degree of decomposition, recalcitrance and turnover rate among which active pool responds quickly to the change in the land use system or other management 
practices (Huang et al., 2008). Offiong et al., (2009) reported that the levels of SOC, total N and cation exchange capacity (CEC) were substantially higher in soils of the undisturbed secondary forest than in soils adjoining the road. Freixo et al., (2002) studied the effect of tillage on soil $\mathrm{C}$ and $\mathrm{N}$ content and their fractions under two cropping systems wheat/soybean and vetch/maize. They compared it with uncultivated soil adjacent to field and concluded that higher amount of $\mathrm{C}$ and $\mathrm{N}$ soil under uncultivated than cultivated in the $0-5 \mathrm{~cm}$ depth.

Land use profoundly influence soil functions at multiple levels within agro ecosystems (Griffin and Broos 2009). Agricultural soil has $50-75 \%$ less C stocks compare to reference site which is under native forest (Spaccini et al., 2001). Singh et al., (2011) revealed that organic carbon content in kitchen garden based land use system is highest $\left(26.1 \mathrm{~g} \mathrm{~kg}^{-1}\right)$ followed by natural forest $\left(23.6 \mathrm{~g} \mathrm{~kg}^{-1}\right)$ and lowest under low land paddy $\left(9.1 \mathrm{~g} \mathrm{~kg}^{-1}\right)$. Highest SOC under natural forest is due to the continuous addition of litter fall and lower addition of organic matter and intensive tillage reduces the organic carbon in the paddy land use system. Saha et al., (2011) reported that the SOC in surface soils significantly decreased by $27 \%$ in forest and $45 \%$ in agricultural land whereas Geissen et al., (2009) contradict to the former findings and concluded significantly higher SOC content

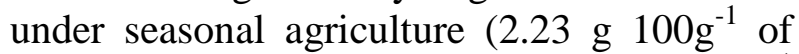
soil) than under fruit plantations $\left(1.16{\mathrm{~g} 100 \mathrm{~g}^{-1}}^{-1}\right.$ of soil) while other land use system such as sugarcane, forest, primary and secondary forest and pasture does not show any significant difference and ranged 1.85 to 2.70 $\mathrm{g} 100 \mathrm{~g}^{-1}$ of soil content of SOC. Gupta et al., (2014) revealed that the maximum SOC was under forest $(37.61 \mathrm{t} / \mathrm{ha})$ followed by horticulture (27.26 t/ha), agriculture (17.72 t/ha) and agro forestry land use system (10.84 t/ha).
Datta et al., (2015) concluded that soil under guava plantation recorded highest SOC storage (61.0 $\mathrm{Mg} \mathrm{C} \mathrm{ha}^{-1}$ ) upto the depth of 60 $\mathrm{cm}$. However, a reverse trend of soil fertility was observed as agriculture > agri-horti-silvipastoral > livestock based farming system (Majumdar et al., 2002 and Singh et al., 2003). Lakaria et al., (2012) reported that forest and organic farming systems have higher SOC content but the mineralization rate was found to be the minimum as compared to farmer's practices. An increase in SOC levels is directly linked to the amount and quantity of organic residues return to the soils (Mandal et al., 2007). After each change in the land use system a new quasi-equilibrium stage is arrived over a period of constant management in terms of new land use pattern, vegetation cover and management practices (Bhattacharyya et al., 2008). The dynamics of SOC with change in land use and management can better be explained by the way $\mathrm{C}$ is allocated in different fractions of soil organic matter (Tan et al., 2007).

\section{Organic carbon fractions}

Microbial biomass plays a dual role in the soil, first as an agent for the decomposition of plant residues, with concurrent release of nutrients and second as labile pool of nutrition. Most soil organic carbon is constituted $1-3 \%$ by $\mathrm{MBC}$ and due to its rapid turnover rate make it important potential source of nutrients (Stevenson, 1982).

Microbial biomass carbon (MBC) corresponds to a small portion of total organic carbon and is sensitive to variations in land-use and soil management practices which provide indications of changes and future trends in SOM caused by modified management practices (Llorente and Turrion, 2009). Land use/land cover changes (degradation of natural forest and subsequent cultivation of soils) resulted in significant decreases in microbial 
biomass (Islam et al., 2000). The decreases in soil microbial biomass and microbial biomass to total organic matter ratio by intensification of cropping systems was also reported by Bradley et al., (2001). Microbial biomass carbon was reported higher (430.7 $\mu \mathrm{g} \mathrm{g}^{-1}$ ) (Table 1) under forest land use system followed by organic farming $\left(230.0 \mu \mathrm{g} \mathrm{g}^{-1}\right)$ land use system while both these system are significantly higher in MBC as compared to agricultural and riverine land (Lakaria et al., 2012). Contrasting these findings, Hungria et al., (2009) observed that the microbial biomass was not clearly affected by different land use systems.

Soil solution contains varying amounts of dissolve organic carbon (DOC) which originates from plant litter, soil humus (Mc Dowell and Lickens, 1988), and microbial biomass from root exudates. Although DOC comprises of small fractions of soil organic carbon, it acts as a buffering agent in replenishment mechanism like desorption from soil colloids, dissolution from litter, and exudation from plant roots (Six et al., 2000). Dissolved organic carbon is an important component of $\mathrm{C}$ cycling and it is supposed to be most active and mobile form of organic matter in soil and considered as indicator of soil health (Kalbitz et al., 2000; Royer et al., 2007; Pan et al., 2010). Although DOC represents only small parts of $\mathrm{C}$ pools, it appears to be involved in many processes, such as translocation of nutrient and their biogeochemistry of $\mathrm{N}$ and $\mathrm{P}$ (Kalbitz et al., 2000) microbial decomposer activities (Peichl et al., 2007).

Studies conducted in arable soils demonstrated that quality of dissolved organic matter was highly related to soil and management associated factors rather than seasonality (Embacher et al., 2007, 2008). Lakaria et al., (2012) studied different pools of organic carbon under dominant land use systems in a
Vertisol of Central India. They observed that the SOC pools viz., water soluble carbon was the highest under forest land use system [eucalyptus (Eucalyptus globules), mahua (Madhuca longifolia) and tendu (Diospyros melanoxylo) and horticulture [mango (Mangifera indica)] plantation. They also reported that among agriculture land use systems, the continuous application of farmyard manure (FYM) @ $6 \mathrm{t} \mathrm{ha}^{-1} \mathrm{yr}^{-1}$ to soybean-wheat cropping system significantly increased DOC. Under agri-horticulture system aonla (Emblica officinalis) and guava (Psidium guajava) plantations along with gram as rabi season companion crop improved the DOC.

Light fraction carbon (LFC) comprised largely of incompletely decomposed organic residues, may provide a sensitive indicator of the effects of cropping practices on soil organic matter (Stevenson 1982). Chemical analysis indicates that LFC material is intermediate between plant material and humified organic matter with regard to carbohydrate composition, amino acid composition, and $\mathrm{C} / \mathrm{N}$ ratio (Greenland, 1971; Oades and Ladd, 1977; Turchenek and Oades, 1979).

Because of its high density, clay-associated organic material is excluded and the LF, therefore, consists primarily of "free" organic matter (Greenland and Ford, 1964). Light fraction is mainly derived from plant residues, but it also contains appreciable amounts of microbial and micro faunal debris including fungal hyphae and spores (Molloy and Speir, 1977; Spycher et al., 1983).

Dalal and Mayer (1987) concluded that the different land use system and management practices that enhance the amount of light fraction would increase the rate of nutrient cycling through microbial biomass and may increase the overall availability of nutrients in soil (Table 2). 
Table.1 Soil organic carbon, water soluble carbon, labile carbon, soil microbial biomass carbon and microbial count under different land use systems

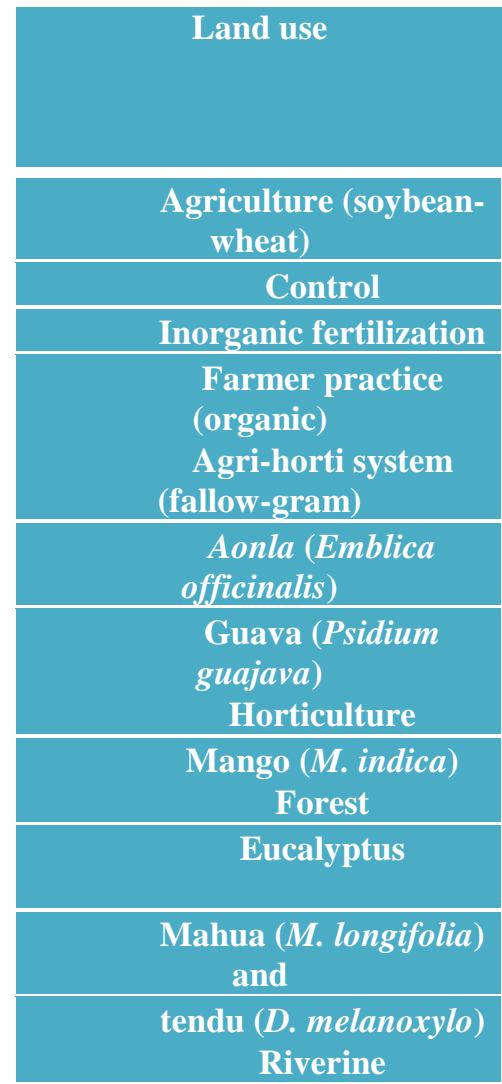

Near river-bed

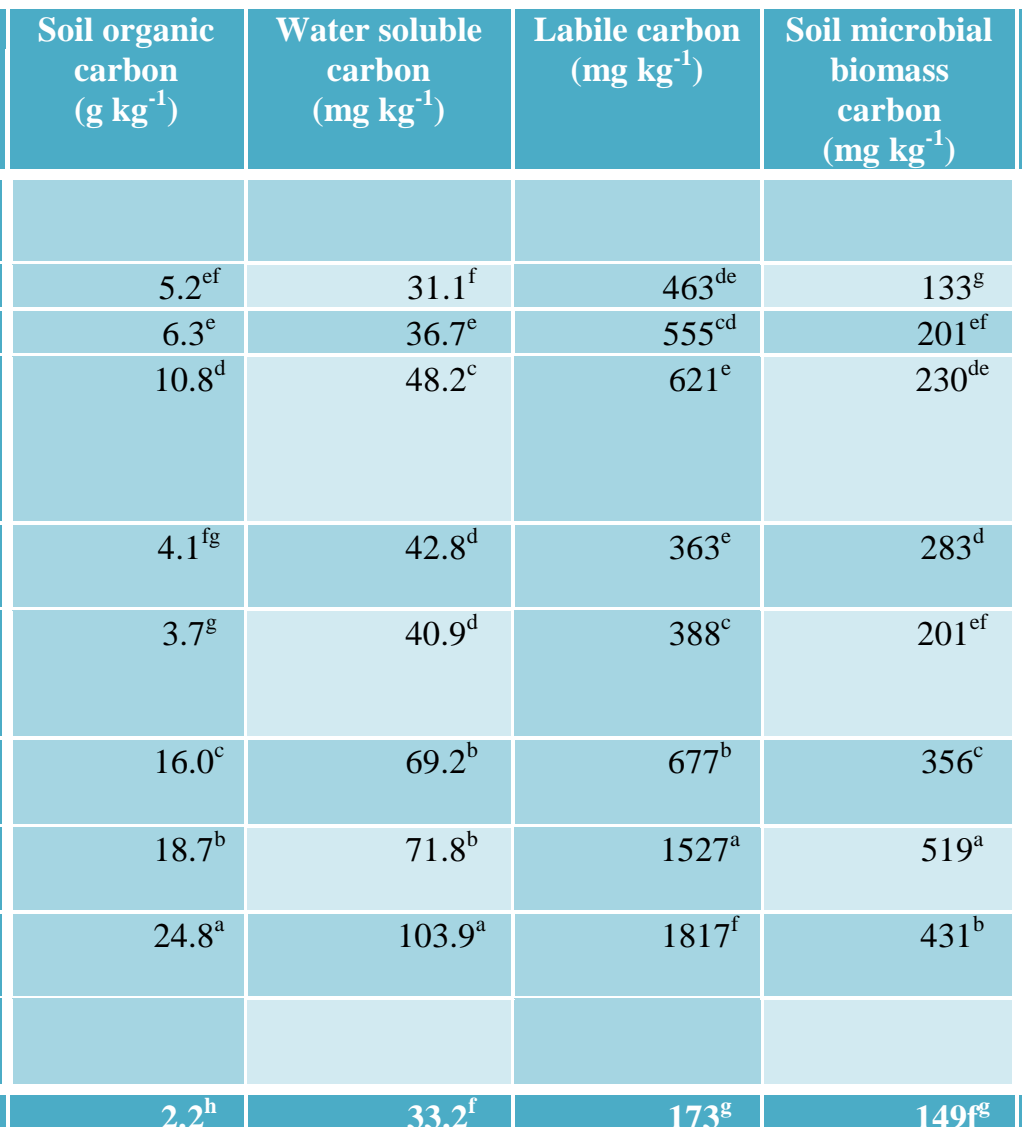

Microbial

count $\left(\times 10^{4}\right)$

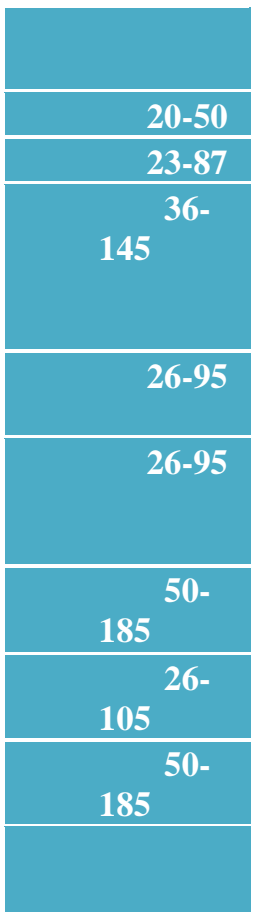

The difference between values in a column followed by different superscripts is significant at $\mathrm{P}<0.05$ (Source: Lakaria et al., 2012)

Table.2 Total C, inorganic C (SIC), total organic C (TOC), soil organic C (SOC) and total N concentration in soils of agroforestry, rice-wheat, and maize-wheat systems in the Rupnagar district of Indian Punjab

\begin{tabular}{|c|c|c|c|c|c|}
\hline Land-use & $\begin{array}{l}\text { Total C (g } \\
\mathrm{kg}^{-1} \text { soil) }\end{array}$ & $\begin{array}{l}\text { SIC }\left(\mathrm{g} \mathrm{kg}^{-1}\right. \\
\text { soil) }\end{array}$ & $\begin{array}{l}\text { TOC }\left(\mathrm{g} \mathrm{kg}^{-1}\right. \\
\text { soil) }\end{array}$ & $\begin{array}{l}\text { SOC }\left(\mathrm{g} \mathrm{kg}^{-1}\right. \\
\text { soil) }\end{array}$ & $\begin{array}{l}\text { Total N (g } \\
\mathrm{kg}^{-1} \text { soil) }\end{array}$ \\
\hline Agroforestry & $\begin{array}{l}8.83^{\mathrm{a}} \\
(0.83)\end{array}$ & $\begin{array}{r}0.48^{\mathrm{a}} \\
(0.08)\end{array}$ & $\begin{array}{l}8.35^{\mathrm{a}} \\
(0.80)\end{array}$ & $\begin{array}{l}6.56^{\mathrm{a}} \\
(0.53)\end{array}$ & $\begin{array}{l}1.1^{\mathrm{a}} \\
(0.08)\end{array}$ \\
\hline Maize-wheat & $\begin{array}{l}8.95^{\mathrm{a}} \\
(0.79)\end{array}$ & $\begin{array}{l}0.89^{\mathrm{a}} \\
(0.20)\end{array}$ & $\begin{array}{l}8.06^{\mathrm{a}} \\
(0.70)\end{array}$ & $\begin{array}{l}6.52^{\mathrm{a}} \\
(0.51)\end{array}$ & $\begin{array}{l}0.73^{b} \\
(0.06)\end{array}$ \\
\hline Rice-wheat & $\begin{array}{l}6.90^{\mathrm{a}} \\
(1.32)\end{array}$ & $\begin{array}{c}0.40^{\mathrm{a}} \\
(0.20)\end{array}$ & $\begin{array}{l}6.50^{\mathrm{a}} \\
(1.41)\end{array}$ & $\begin{array}{l}3.88^{\mathrm{b}} \\
(0.89)\end{array}$ & $\begin{array}{l}0.61^{\mathrm{b}} \\
(0.10)\end{array}$ \\
\hline LSD (0.05) & NS & NS & NS & 1.89 & 0.24 \\
\hline
\end{tabular}

Mean values in a column followed by same letter are not significantly different at $P>0.05$. NS $=$ non-significant

Values in parenthesis indicate standard error of mean (Source: Benbi et al., 2011) 
Int.J.Curr.Microbiol.App.Sci (2018) 7(8): 1578-1591

Table.3 Chemical properties of soils under different land use systems

\begin{tabular}{|c|c|c|c|c|c|}
\hline Soil properties & $\begin{array}{c}\text { Cropped } \\
\text { area }\end{array}$ & $\begin{array}{c}\text { Leucaena } \\
\text { leucocephala }\end{array}$ & $\begin{array}{l}\text { Grassland } \\
\text { area }\end{array}$ & $\begin{array}{l}\text { Ravine } \\
\text { under MF }\end{array}$ & $\begin{array}{l}\text { Ravine } \\
\text { under AS }\end{array}$ \\
\hline pH & $\begin{array}{c}7.78^{a} \\
(0.012)\end{array}$ & $\begin{array}{c}7.04^{\mathrm{c}} \\
(0.062)\end{array}$ & $\begin{array}{c}7.32^{b} \\
(0.012)\end{array}$ & $\begin{array}{c}7.81^{a} \\
(0.167)\end{array}$ & $\begin{array}{c}8.01^{a} \\
(0.044)\end{array}$ \\
\hline $\mathrm{EC}\left(\mathrm{dS} \mathrm{m}^{-1}\right)$ & $\begin{array}{c}0.48^{a} \\
(0.009)\end{array}$ & $\begin{array}{c}0.32^{b} \\
(0.058)\end{array}$ & $\begin{array}{c}0.26^{b} \\
(0.015)\end{array}$ & $\begin{array}{c}0.45^{\mathrm{a}} \\
(0.035)\end{array}$ & $\begin{array}{l}0.44^{a} \\
(0.025\end{array}$ \\
\hline $\operatorname{SOC}(\%)$ & $\begin{array}{l}0.48^{\mathrm{b}} \\
(0.01)\end{array}$ & $\begin{array}{l}0.69^{a} \\
(0.07)\end{array}$ & $\begin{array}{c}0.76^{\mathrm{ab}} \\
(0.01)\end{array}$ & $\begin{array}{l}0.63^{\mathrm{a}} \\
(0.03)\end{array}$ & $\begin{array}{r}0.45^{\mathrm{ab}} \\
(0.11)\end{array}$ \\
\hline 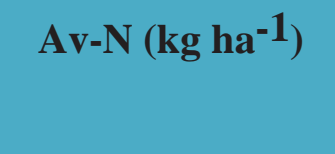 & $\begin{array}{c}277.33^{c} \\
(3.71)\end{array}$ & $\begin{array}{c}365.00^{\mathrm{ab}} \\
(5.51)\end{array}$ & $\begin{array}{c}390.33^{a} \\
(1.67)\end{array}$ & $\begin{array}{c}291.67^{c} \\
(1.33)\end{array}$ & $\begin{array}{r}222.0 \mathrm{bc} \\
(8.62)\end{array}$ \\
\hline $\operatorname{Av-P}\left(\operatorname{kg~ha}^{-1}\right)$ & $\begin{array}{l}14.45^{\mathrm{c}} \\
(0.33)\end{array}$ & $\begin{array}{l}23.86^{a} \\
(0.87)\end{array}$ & $\begin{array}{l}23.82^{a} \\
(0.95)\end{array}$ & $\begin{array}{l}20.09^{b} \\
(0.80)\end{array}$ & $\begin{array}{r}17.37 b^{c} \\
(1.50)\end{array}$ \\
\hline $\operatorname{Av}-K\left(k_{g ~ h a-1}\right)$ & $\begin{array}{c}403.33^{\mathrm{a}} \\
(5.90)\end{array}$ & $\begin{array}{l}421.00^{b} \\
(17.62)\end{array}$ & $\begin{array}{l}473.00^{b} \\
(41.74)\end{array}$ & $\begin{array}{c}430.00^{b} \\
(8.66)\end{array}$ & $\begin{array}{r}563.00^{\mathrm{b}} \\
(10.54)\end{array}$ \\
\hline $\begin{array}{c}\mathrm{Na}\left[\mathrm{c} \mathrm{mol}(\mathrm{p}+) \mathrm{kg}^{-}\right. \\
\mathbf{1}_{1}\end{array}$ & $\begin{array}{l}3.37 \mathrm{ab} \\
(0.20)\end{array}$ & $\begin{array}{l}3.91^{\mathrm{a}} \\
(0.09)\end{array}$ & $\begin{array}{l}3.08^{a b} \\
(0.40)\end{array}$ & $\begin{array}{l}2.97 b \\
(0.39)\end{array}$ & $\begin{array}{c}3.51 \mathbf{a}^{\mathbf{b}} \\
(0.06)\end{array}$ \\
\hline $\begin{array}{c}\mathrm{Ca}\left[\mathrm{c} \mathrm{mol}(\mathrm{p}+) \mathrm{kg}^{-}\right. \\
\mathbf{1}_{1}\end{array}$ & $\begin{array}{l}26.37^{\mathrm{bc}} \\
(3.23)\end{array}$ & $\begin{array}{l}12.24^{\mathrm{d}} \\
(2.09)\end{array}$ & $\begin{array}{l}19.17^{\mathrm{cd}} \\
(1.49)\end{array}$ & $\begin{array}{c}32.13^{\mathrm{ab}} \\
(2.37\end{array}$ & $\begin{array}{l}37.97 \mathbf{a} \\
(3.77)\end{array}$ \\
\hline $\begin{array}{c}\mathrm{Mg}\left[\mathrm{c} \mathrm{mol}(\mathrm{p}+) \mathrm{kg}^{-}\right. \\
\mathbf{1}^{-}\end{array}$ & $\begin{array}{l}7.73^{b} \\
(0.34)\end{array}$ & $\begin{array}{l}7.14^{b} \\
(0.03)\end{array}$ & $\begin{array}{l}6.80^{b c} \\
(0.30)\end{array}$ & $\begin{array}{l}4.50^{\mathrm{c}} \\
(1.20)\end{array}$ & $\begin{array}{l}14.90^{\mathrm{a}} \\
(1.23)\end{array}$ \\
\hline $\begin{array}{c}\text { CEC [c mol } \\
\left.(p+) \mathrm{kg}^{-1}\right]\end{array}$ & $\begin{array}{l}31.20^{a} \\
(0.72)\end{array}$ & $\begin{array}{l}24.92^{a} \\
(0.57)\end{array}$ & $\begin{array}{c}18.34 \mathrm{~b} \\
(1.37)\end{array}$ & $\begin{array}{l}15.44 \mathrm{~b} \\
(1.41)\end{array}$ & $\begin{array}{c}12.96 \mathrm{~b} \\
(0.58)\end{array}$ \\
\hline
\end{tabular}

Values are in parenthesis indicate standard errors. Different alphabet along row indicates significant effect. (Source: Somasundaram et al., 2014) 
Table.4 Effect of land-use systems on chemical properties of soil

\begin{tabular}{|c|c|c|c|c|c|}
\hline $\begin{array}{l}\text { System } \\
\downarrow\end{array}$ & $\begin{array}{l}\text { Soil layer(cm) } \\
\rightarrow\end{array}$ & $0-15$ & $15-30$ & $30-45$ & $45-60$ \\
\hline \multicolumn{6}{|l|}{ pH } \\
\hline \multicolumn{2}{|l|}{ Forest } & 5.22 & 5.30 & 5.34 & 5.21 \\
\hline \multicolumn{2}{|c|}{ Grassland } & 5.69 & 5.70 & 5.61 & 5.72 \\
\hline \multicolumn{2}{|c|}{ Horticulture } & 5.46 & 5.56 & 5.50 & 5.59 \\
\hline \multicolumn{2}{|c|}{ Agriculture } & 5.50 & 5.49 & 5.53 & 5.53 \\
\hline \multicolumn{2}{|c|}{ Wasteland } & 5.60 & 5.69 & 5.65 & 5.64 \\
\hline \multicolumn{2}{|l|}{$\mathrm{LSD}_{0.05}$} & $\mathrm{~L}=0.12$ & $\mathrm{D}=\mathrm{NS}$ & $\mathrm{L} \times \mathrm{D}=\mathrm{NS}$ & \\
\hline \multicolumn{6}{|c|}{ Organic carbon $(\%)$} \\
\hline \multicolumn{2}{|l|}{ Forest } & 3.01 & 2.29 & 1.86 & 1.25 \\
\hline \multicolumn{2}{|c|}{ Grassland } & 2.16 & 1.85 & 1.69 & 1.17 \\
\hline \multicolumn{2}{|c|}{ Horticulture } & 1.68 & 1.52 & 1.04 & 1.23 \\
\hline \multicolumn{2}{|c|}{ Agriculture } & 0.90 & 0.65 & 0.49 & 0.36 \\
\hline \multicolumn{2}{|c|}{ Wasteland } & 0.85 & 0.56 & 0.50 & 0.45 \\
\hline \multicolumn{2}{|c|}{$\mathrm{LSD}_{0.05}$} & $\mathrm{~L}=0.045$ & $\mathrm{D}=0.006$ & $0.031 \quad \mathrm{~L} \times \mathrm{D}=$ & \\
\hline \multicolumn{6}{|c|}{$\begin{array}{l}\text { Electrical conductivity } \\
\qquad\left(\mathrm{dS} \mathrm{m}^{-1}\right)\end{array}$} \\
\hline \multicolumn{2}{|c|}{ Forest } & 0.24 & 0.26 & 0.24 & 0.26 \\
\hline \multicolumn{2}{|c|}{ Grassland } & 0.25 & 0.25 & 0.25 & 0.24 \\
\hline \multicolumn{2}{|c|}{ Horticulture } & 0.25 & 0.23 & 0.22 & 0.26 \\
\hline \multicolumn{2}{|c|}{ Agriculture } & 0.22 & 0.22 & 0.25 & 0.25 \\
\hline \multicolumn{2}{|c|}{ Wasteland } & 0.23 & 0.22 & 0.25 & 0.26 \\
\hline \multicolumn{2}{|l|}{$\mathrm{LSD}_{0.05}$} & $\mathrm{~L}=\mathrm{NS}$ & $\mathrm{D}=\mathrm{NS}$ & $\mathrm{L} \times \mathrm{D}=\mathrm{NS}$ & \\
\hline \multicolumn{6}{|c|}{$\begin{array}{l}\text { Cation exchange capacity } \\
\qquad(\mathrm{c} \mathrm{mol} \mathrm{kg} \\
\end{array}$} \\
\hline \multicolumn{2}{|c|}{ Forest } & 15.20 & 15.01 & 14.42 & 15.12 \\
\hline \multicolumn{2}{|c|}{ Grassland } & 15.81 & 15.01 & 15.00 & 14.96 \\
\hline \multicolumn{2}{|c|}{ Horticulture } & 14.90 & 14.65 & 13.98 & 14.21 \\
\hline \multicolumn{2}{|c|}{ Agriculture } & 14.30 & 13.65 & 14.35 & 13.87 \\
\hline \multicolumn{2}{|c|}{ Wasteland } & 13.80 & 13.23 & 13.01 & 14.20 \\
\hline \multicolumn{2}{|l|}{$\mathrm{LSD}_{0.05}$} & $\mathrm{~L}=\mathbf{0 . 2 5}$ & $\mathrm{D}=\mathrm{NS}$ & $\mathrm{L} \times \mathrm{D}=\mathrm{NS}$ & \\
\hline
\end{tabular}

Note. L - Land-use system, D - Soil layer, NS - Non significant. LSD, least significant difference at the 5\% probability level. (Source: Pal et al., 2013) 
Table.5 Effect of land-use systems on available nutrients in soil profile

\begin{tabular}{|c|c|c|c|c|c|}
\hline $\begin{array}{l}\text { System } \\
\downarrow\end{array}$ & $\begin{array}{l}\text { Soil layer }(\mathrm{cm}) \\
\rightarrow\end{array}$ & $0-15$ & $15-30$ & $30-45$ & $45-60$ \\
\hline \multicolumn{6}{|c|}{ Available nitrogen $\left(\mathrm{kg} \mathrm{ha}^{-1}\right)$} \\
\hline & Forest & 699 & 654 & 623 & 597 \\
\hline & Grassland & 426 & 401 & 395 & 352 \\
\hline & Iorticulture & 401 & 357 & 346 & 321 \\
\hline & Igriculture & 301 & 295 & 258 & 278 \\
\hline & Wasteland & 286 & 249 & 271 & 250 \\
\hline \multicolumn{3}{|c|}{$\mathrm{LSD}_{0.05} \mathrm{~L}=16.25$} & $\mathrm{D}=7.21$ & $\mathrm{~L} \times \mathrm{D}=12.43$ & \\
\hline \multicolumn{6}{|c|}{ Available phosphorus (kg ha $\left.{ }^{-1}\right)$} \\
\hline & Forest & 17.23 & 16.44 & 16.21 & 15.01 \\
\hline & Grassland & 15.47 & 14 & 13.91 & 13 \\
\hline & Iorticulture & 13.24 & 12.9 & 14.23 & 13.21 \\
\hline & Igriculture & 12.31 & 12 & 11.96 & 10.90 \\
\hline & Wasteland & 11.48 & 10.21 & 11.12 & 12.13 \\
\hline $\mathrm{LSD}_{\mathbf{0 . 0 5}}$ & & $=0.21$ & $\mathrm{D}=\mathrm{NS}$ & $\mathrm{L} \times \mathrm{D}=\mathrm{NS}$ & \\
\hline \multicolumn{6}{|c|}{ Available potassium $\left(\mathrm{kg} \mathrm{ha}^{-1}\right)$} \\
\hline \multicolumn{2}{|r|}{ Forest } & 301.61 & 295.4 & 290.1 & 287.3 \\
\hline \multicolumn{2}{|r|}{ Grassland } & 285.21 & 273.1 & 282.72 & 267.5 \\
\hline \multicolumn{2}{|c|}{ Horticulture } & 271.5 & 267 & 254 & 265 \\
\hline \multicolumn{2}{|c|}{ Agriculture } & 265 & 278 & 264 & 276 \\
\hline \multicolumn{2}{|r|}{ Wasteland } & 264 & 278 & 254 & 267 \\
\hline \multicolumn{3}{|c|}{$\mathrm{L}=13.25$} & $\mathrm{D}=\mathrm{NS}$ & $\mathbf{L} \times \mathbf{D}=\mathbf{N S}$ & \\
\hline
\end{tabular}

Note. L - Land-use system, D - Soil layer, NS - Non significant. LSD, least significant difference at the 5\% (Source: Pal et al., 2013)

Light fraction carbon is associated with nonaggregated soil and it is not ready losing from any tillage practices, and it easily accumulated in microbial biomass compared to other C fractions (David et al., 2006).

Soil under no tillage and forest preserved respectively $167 \%$ and $94 \%$ more LFC than those under conventional tillage. The mass of LFC decreased with an increase in soil depth.

Carbon concentration in heavy fraction average $20,10,8 \mathrm{~g} \mathrm{~kg}^{-1}$ under no tillage, forest and conventional tillage land use system respectively (Tan et al., 2007). Carbon heavy fraction represented highest fraction in soil and corresponded to $82 \%$ of total organic carbon (TOC) at depth of 0-20 cm and arable land site tended to present the lowest value of heavy fraction carbon (HFC) at $0-10 \mathrm{~cm}$ depth $\left(7.2 \mathrm{Mg} \mathrm{ha}^{-1}\right)$ as compared to silvopasture system (Matos et al., 2011). Wu et al., (2003) revealed that lower amount of HFC $(7.8 \mathrm{Mg}$ $\mathrm{ha}^{-1}$ ) in $0-10 \mathrm{~cm}$ layer of continuous cultivated soil as compared to soil which is under pasture from more than 10 years after 70 years of arable cultivation.

Sekhon et al., (2009) revealed that significantly higher HFC content was observed in rice-wheat cropping system which was amended with pressmud and FYM because mature compost have higher of stable product which constitute the HFC. 


\section{Available nutrient status in Soil}

Soils under particular land use system may affect physic-chemical properties which may modify fertility status and nutrient availability to plants (Sharma et al., 2013). The soil solution concentration of $\mathrm{N}, \mathrm{P}, \mathrm{S}$ and several micronutrients are intimately related to organic fraction in soil (Havlin et al., 2005). Schipper and Sparling (2000) suggested that land use change modifications are biologically and chemically more rapid than are physically. Conversion of native forests and pristine soils to cultivation is usually accompanied by decline in SOC and deterioration of soil structure. Trees had long been found to increase organic carbon, extractable $\mathrm{P}$, and exchangeable cations (Tomlinson et al., 1995)

Land use pattern also plays a vital role in governing the nutrient dynamics and fertility of soils (Venkatesh et al., 2003). Offiong et al., (2009) reported that the levels of SOC, total $\mathrm{N}$ and CEC were substantially higher in soils of the undisturbed secondary forest than in soils adjoining the road. In Indian condition, Somasundaram et al., (2014) observed higher amount of available nitrogen, phosphorous, potassium and CEC in soil under natural vegetation compared to other land use system (Table 3). The status micronutrients under different land use system varies as $\mathrm{Mn}>\mathrm{Fe}>\mathrm{Zn}>\mathrm{Cu}$ which was lower in agricultural fields and ravine lands as compared to other land uses (Table). Singh and Bordoloi (2011) noted that uncultivated land recorded the maximum (308 $\mathrm{kg} \mathrm{ha}^{-1}$ ) potassium content followed by natural forest $\left(218 \mathrm{~kg} \mathrm{ha}^{-1}\right)$ and jhum cultivation (205 kg $\mathrm{ha}^{-1}$ ). They also found higher amount of available $\mathrm{Zn}\left(4.2 \mathrm{mg} \mathrm{kg}^{-1}\right)$ was recorded in citrus orchard based land use system than pineapple orchard and higher amount of $\mathrm{Fe}$ was recorded by under low land paddy land use system compared to other system due to reduced conditions. Land use changes from forest and grazing lands to cultivated land increased the contents of basic extractable $(\mathrm{Ca}, \mathrm{Mg}$ and $\mathrm{K})$ ions and decreased the contents of extractable $\mathrm{Al}$ and $\mathrm{Fe}$ ions resulting in lower contents of total $\mathrm{P}$ in soils of the cultivated land than the remaining land use types (Chimdi et al., 2014). Chhibba et al., (2007) studied the nutrient availability in different land use system of Punjab and observed $14 \%$ more available phosphorus content in cotton-wheat system than that in the rice-wheat system. However, $15.5 \%$ more available potassium was observed in ricewheat system than cotton- wheat system. The DTPA- extractable $\mathrm{Zn}, \mathrm{Fe}, \mathrm{Mn}$, and $\mathrm{Cu}$, were significantly greater in the surface soil under rice-wheat than that under the cotton-wheat system (Table 4 and 5).

The conversion of forest land into agriculture for crop cultivation decreased the soil organic carbon content and nutrient availability. The dynamics of SOC with change in land use and management can better be explained by the way $\mathrm{C}$ is allocated in different fractions of soil organic matter. The available nutrient in cultivated soil was also decreased as compared to uncultivated soil and natural forest.

\section{References}

Apezteguia, H.P., Izaurralde, R.C. and Sereno, R. (2009) Simulation study of soil organic matter dynamics as affected by land use and agricultural practices in semi-arid Cordoba, Argentina. Soil and Tillage Research, 102, 101-108.

Bayer, C. and Mielniczuk, J. (2008) Organic matter dynamics and function. (eds. Santos, G.A.; Silva, L.S.; Canellas, L.P.; Camargo, F.A.O.), Fundamentals of soil organic matter: tropical and subtropical ecosystems. pp. 7-18. Ed. 
Metrópole, Porto Alegre, RS, Brazil. (in Portuguese).

Benbi, D.K. and Senapati, N. (2010) Soil aggregation and carbon and nitrogen stabilization in relation to residue and manure application in rice-wheat systems in northwest India. Nutrient Cycling in Agroecosystems. 87, 233247.

Bhattacharyya, P., Nayak, A.K., Mohanty, S., Tripathi, R., Shahid, M., Kumar, A., Raja, R., Panda, B.B., Roy, K.S., Neogi, S., Dash, P.K., Shukla, A.K. and Rao, K.S. (2013) Greenhouse gas emission in relation to labile soil $\mathrm{C}, \mathrm{N}$ pools and functional microbial diversity as influenced by 39 years long-term fertilizer management in tropical rice. Soil and Tillage Research, 129, 93-105.

Bradley, P., Deegens, A.L., Sparling, G.P. and Duncan, L.C. (2001) Is the microbial community in a soil with reduced catabolic diversity less resistant to stress or disturbance. Soil Biology and Biochemistry, 33(4), 1143-1153.

Cantarella, H. (2007) Nitrogen. (eds. R.F.; Alvarez, V.; Barros, N.F.; Fontes, R.L.F.; Cantarutti, R.B.; Neves, J.C.L.), Soil fertility. Sociedade Brasileira de Ciência do Solo, pp. 375-470. Viçosa, MG, Brazil. (in Portuguese).

Chimdi, A., Esala, M. and Ylivainio, K. (2014) sequential fractionation patterns of soil phosphorus collected from different land use systems of dire inchine District, West Shawa Zone, Ethiopia. American-Eurasian Journal of Scientific Research, 9(3), 51-57.

Christensen, B.T. (1992) Physical fractionation of soil and organic matter in primary particle size and density separates. In Stewart, B.A.(eds). Advances in Soil Sciences. 20, 1-90.

Dalal, R.C. and Mayer, R.J. (1987) Long term trends in fertility of soils under continuous cultivation and cereal cropping in southern Queensland VII. Dynamics of nitrogen mineralization potentials and microbial biomass. Australian Journal of Soil Research. 25, 461-472.

Datta, A., Basak, N., Chaudhari, S.K. and Sharma, D.K. (2015) Effect of horticultural land uses on soil properties and organic carbon distribution in a reclaimed sodic soil. Journal of the Indian Society of Soil Sciences, 63(3), 294-303.

David, S., Yusmary, E. and Rafael, R. (2006) Short-term tillage practices on soil organic matter pools in a tropical Ultisol. Australian Journal of Soil Research, 44, 687-693.

Embacher, A., Zsolnay, A., Gatinger, J.D. and Munch, J.C. (2007) The dynamics of water extractable organic matter (WEOM) in common arable topsoils: I. Quantity, quality and function over a three-year period. Geoderma, 139, 1122.

Embacher, A., Zsolnay, A., Gatinger, J.D. and Munch, J.C. (2008) The dynamics of water extractable organic matter (WEOM) in common arable topsoils: II. Influence of mineral and combined mineral and manure fertilization in a Haplic Chernozem. Geoderma, 148, 6369.

Freixo, A.A., Machado, P.L. and Santos, H.P. (2002) Soil organic carbon and fractions of Rhodic Ferralsol under the influence of tillage and crop rotation systems in Southern Brazil. Soil and Tillage Research, 64, 221-230.

Geissen, V., Pena-Pena, K. and Huerta, E. (2009) Effects of different land use on soil chemical properties, decomposition rate and earthworm communities in tropical Mexico. Pedobiologia, 53, 7586.

Geissen, V., Pena-Pena, K. and Huerta, E. (2009) Effects of different land use on 
soil chemical properties, decomposition rate and earthworm communities in tropical Mexico. Pedobiologia, 53, 7586.

Greenland, D.J. (1971) Changes in the nitrogen status and physical condition of soils under pastures, with special reference to the maintenance of the fertility of Australian soils used for growing wheat. Soils and fertilisers, 34, 237-251.

Greenland, D.J. and Ford, G.W. (1964) Separation of partially humified organic materials from soils by ultrasonic dispersion. Transactions of the eighth international congress of soil science, Bucharest, 3, 137-148.

Griffin, T. and Broos, K. (2009) Building a foundation for soil condition assessment. CSIRO Land and Water Science Report by P.H. Bellamy, P.J. Loveland, R.I. Bradley.

Guo, L.B. and Gifford, R.M. (2002) Soil carbon stocks and land use change: a meta analysis. Global Change Biology, 8, 345-360.

Gupta, M.K., Sharma, S.D. and Kumar, M. (2014) Status of sequestered organic carbon in the soils under different land uses in southern region of Haryana. International Journal of Science, Environment and Technology, 3, 811826.

Haile, S.G., Nair, P.K.R. and Nair, V.D. (2008) Carbon storage of different soilsize fractions in Florida silvopastoral systems. Journal of Environmental Quality, 37, 1789-1797.

Havlin, J.L., Tisdale, S.L., Beaton, J.D. and Nelson, W.L. (2005) Soil Fertility and Nutrient Management. $7^{\text {th }}$ edition. Pearson Prentice Hall, Upper Saddle River, NJ.

Houghton, R.A. (1999) The annual net flux of carbon to the atmosphere from changes in land use 1850-1990. Tellus, 51B, 298-313.

Huang, Q.R., Hu, F., Huang, S., Li, H.X., Yuan, Y.H., Pan, G.X. and Zhang, W.J. (2008) Effect of long-term fertilization on organic carbon and nitrogen in a subtropical paddy soil. Pedosphere, 19(6), 727-734.

Hungria, M., Franchini, J.C., Brandao-Junior, O., Kaschuk, G. and Souza, R.A. (2009) Soil microbial activity and crop sustainability in a long-term experiment with three soil-tillage and two croprotation systems. Applied Soil Ecology, 42, 288-296.

Islam, K.R. and Weil, R.R. (2000) Land use effects on soil quality in a tropical forest ecosystem of Bangladesh. Agriculture, Ecosystems and Environment, 79, 9-16.

Kalbitz, K., Solinger, S., Park, J.H., Michalzik, B. and Matzner, E. (2000) Controls on the dynamics of dissolved organic matter in soils: a review. Soil Science, 165, 277-304.

Lakaria, B.L., Mukherjee, A., Jha, P. and Biswas, A.K. (2012) Soil carbon mineralization as affected by land use systems and water regimes. Journal of the Indian Society of Soil Sciences, 60(1), 71-73.

Lal, R. (2002) Soil carbon dynamics in cropland and rangeland. Environmental Pollution, 116, 353-362.

Llorente, M. and Turrion, M. (2009) Microbiological parameters as indicators of soil organic carbon dynamics in relation to different land use management. European Journal of Forest Research, 129(1), 73-81.

Maia, S., Xavie,r F., Oliveira, T., Mendonca, E., Araujo, F.J. (2007) Organic carbon pools in a Luvisol under agroforestry and conventional farming systems in the semi-arid region of Ceara, Brazil. Agroforestry Systems, 71, 127-138. doi: 10.1007/s10457-007-9063-8. 
Majumdar, B., Venkatesh, M.S., Satapathy, K.K., Kumar, K. and Patiram. (2002) Effect of alternative farming systems to shifting cultivation on soil fertility. Indian Journal of Agricultural Sciences, 72(2), 122-124.

Mandal, A., Patra, A.K., Singh, D., Swarup, A. and Masto, R.E. (2007) Effect of long-term application of manure and fertilizer on biological and biochemical activities in soil during crop development stages. Bioresource Technology, 98, 3585-3592.

Martinez-Mena, M., Lopez, J., Almagro, M., Boix-Fayos, C. and Albaladejo, J. (2008) Effect of water erosion and cultivation on the soil carbon stock in a semiarid area of South-East Spain. Soil and Tillage Research, 99(4), 119-129.

Matos, E.S., Freese, D., Mendonca, E.S., Slazak, A. And Huttl, R.F. (2011) Carbon, nitrogen and organic C fractions in topsoil affected by conversion from silvopastoral to different land use systems. Agroforestry Systems, 81, 203-211.

Mc Dowell, W.H. and Lickens, G.E. (1988) Origin, composition and flux of dissolved organic carbon in the Hubbard Brook Valley. Ecological Monographs, 58, 177-195.

Mishra, A., Sharma, S.D. and Khan, G.H. (2002) Rehabilitation of degraded sodic lands during a decade of Dalbergia sissoo plantation in Sultanpur district of Uttar Pradesh, India. Land Degradation and Development, 13, 375-386.

Molloy, L.F. and Speir, T.W. (1977) Studies on a climosequence of soils in tussock grasslands. 12. Constituents of the soil light fraction. New Zealand Journal of Science, 20, 167-177.

Oades, J.M. and Ladd, J.N. (1977) Biochemical properties - metabolism of carbon and nitrogen. pp. 127-60.
Queensland University Press: St. Lucia, Queensland.

Offiong, R.A., and Iwara, A.I. (2012) Quantifying the Stock of Soil Organic Carbon Using Multiple Regression Model in a Fallow Vegetation, Southern Nigeria. Ethiopian Journal of Environmental Studies and Management, 5(2), 166-172. http://dx.doi.org/10.4314/ejesm.v5i2.7

Offiong, R.A., Atu, J.E., Njar, G.N. and Iwara, A.I. (2009) Effects of land use change on soil physio-chemical properties in a South-Southern Nigeria. African Journal of Environmental pollution and Health. 7, 47-51.

Pan, Y.P., Wang, Y.S., Xin, J.Y., Tang, G.Q., Song, T., Wang, Y.H., Li, X.R. and Wu, F.K. (2010) Study of dissolved organic carbon in precipitation in Northern China. Atmospheric Environment, 44, 2350-2357.

Peichl, M., Moore, T.R., Arain, M.A., Dalva, M., Brodkey, D. and Joshua, M. (2007) Concentrations and fluxes of dissolved organic carbon in an age-sequence of white pine forests in Southern Ontario, Canada. Biogeochemistry, 86, 1-17.

Potter, C.S., Matson, P.A., Vitousek, P.M., and Davidson, E.A. (1996) Process modeling of controls on nitrogen trace gas emissions from soils worldwide. Journal of Geophysical Research, 101(D1), 1361-1377.

Royer, I., Angers, D.A., Chantigny, M.H., Simard, R.R. and Cluis, D. (2007) Dissolved organic carbon in runoff and tile-drain water under corn and forage fertilized with hog manure. Journal of Environmental Quality, 36, 855-863.

Saha, D.S., Kukal, S. and Sharma, S. (2011) Land use impacts on SOC fractions and aggregate stability in typic ustochrepts of Northwest India. Plant and Soil, 339, 457-470. 
Schipper, L.A. and Sparling, G.P. (2000) Performance of soil condition indicators across taxonomic groups and land uses. Soil Science Society of American Journal. 64, 300-311.

Sekhon, K.S., Singh, J.P. and Mehla, D.S. (2009) Soil organic pools after seven years of manures and mineral fertilizers application in a rice-wheat rotation. Archives of Agronomy and Soil Science, 55(2), 197-206.

Sharif Abad, J.R., Khosravi, H. and Alamdarlou, E.H. (2014) Assessment the effects of land use changes on soil physicochemical properties in Jafarabad of Golestan province, Iran. Bulletin of Environment, Pharmacology and Life Sciences, 3(3), 296-300.

Sharma, Y.K., Sharma, A. and Sharma, S.K. (2013) An appraisal of Physicochemical characteristics and soil fertility status of forest and rice land use systems in Mokokchung district of Nagaland. Journal of the Indian Society of Soil Sciences, 61(1), 38-43.

Singh, A.K. and Bordoloi, L.J. (2011) Study on soil fertility variation as influenced by land use system and soil depth interaction in acid hill soils of Nagaland. Journal of the Indian Society of Soil Sciences, 59(2), 198-204.

Singh, J., Bora, I.P. and Baruah, A. (2003) Changes in the physio-chemical properties of soil under shifting cultivation with special references to Karbi Anglong district of Assam. Indian Journal of Forestry, 26(2), 116-122.

Singh, R.N., Singh, S., Prasad, S.S., Singh, V.K. and Kumar, P. (2011) Effect of integrated nutrient management on soil fertility, nutrient uptake and yield of rice-pea cropping system on an upland acid soil of Jharkhand. Journal of the Indian Society of Soil Sciences, 59, 158163.
Six, J., Elliott, E.T. and Paustian, K. (2000) Soil macroaggregate turnover and microaggregate formation: a mechanism for $\mathrm{C}$ sequestration under no-tillage agriculture. Soil Biology and Biochemistry, 32, 2099-2103.

Smith, K. (2008) Soil organic carbon dynamics and land-use change. (eds. Braimoh, A.K.,Vlek, P.L.G.), Land use and soil resources. Springer, 9-22.

Somasundaram, J., Singh, R.K., Parandiyal, A.K., Ali, S., Chauhan, V., Sinha, N.K., Lakaria, B.L., Saha, R., Chaudhary, R.S., Coumar, M.V., Singh, R.K. and Simaiya, R.R. (2013) Soil properties under different land use systems in parts of Chambal region of Rajasthan. Journal of Agricultural Physics, 13(2), 139-147.

Spaccini, R., Zena, A., Igwe, C.A., Mbagwu, J.S.C. and Piccolo, A. (2001) Carbohydrates in water stable aggregates and particle size fractions of forested and cultivated soils in two contrasting tropical ecosystem. Biogeochemistry, 53, 1-22.

Spycher, G., Sollins, P. and Rose, S. (1983) Carbon and nitrogen in the light fraction of a forest soil: Vertical distribution and seasonal patterns. Soil Science, 135, 7987.

Stevenson, F.J. (1982) Organic forms of soil nitrogen. Nitrogen in Agricultural Soils (ed F.J. Stevenson), ASA-SSSA, 67122.

Swarup, A., Manna, M.C. and Singh, G.B. (2000) Impact of land use and management practices on organic carbon dynamics in soils of India. Global Climate Change and Tropical Ecosystems, pp. 261-281. CRC Lewis Publishers. Boca Raton, Florida, USA.

Swift, R.S. (2001) Sequestration of carbon by soil. Soil Science, 166, 858-871.

Tan, Z., Lal, R., Owens, L. and Izaurralde, R.C. (2007) Distribution of light and 
heavy fractions of soil organic carbon as related to land and tillage practice. Soil and Tillage Research, 92, 53-59.

Tomlinson H., Teklehaimanot Z., Traoré A., Olapade E. (1995) Soil amelioration and root symbioses of Parkia biglobosa (Jacq.) Benth. in West Africa. Agroforestry Systems, 30, 145-159.

Turchenek, L.W. and Oades, J.M. (1979) Fractionation of organo-mineral complexes by sedimentation and density techniques. Geoderma, 21, 311-343.
Venkatesh, M.S., Majumdar, B., Kumar, Kailash and Patiram (2003) Status of micronutrient cations under various land use systems of Meghalaya. Journal of the Indian Society of Soil Science, 51(1), 60-64.

Wu T, Schoenau JJ, Li F, Qian P, Malhi SS, Shi Y (2003) Effect of tillage and rotation on organic carbon forms of chernozemic soils in Saskatchewan. Journal of Plant Nutrition and Soil Science, $\quad 166, \quad 328-335$. doi:10.1002/jpln.200390051.

\section{How to cite this article:}

Usha Kaushik, Dev Raj, Pooja Rani and Bhardwaj, K.K. 2018. Effect of Cultivation on Organic Carbon Pools and Nutrient Availability in Soil under Different Land Use System: A Review. Int.J.Curr.Microbiol.App.Sci. 7(08): 1578-1591. doi: https://doi.org/10.20546/ijcmas.2018.708.180 